(C) 1988 ISIJ

IIIIIIIIIIIIIIIIIIIIII

技術報告

/////////////////////////

\title{
高温，高品質スラブ製造のための連続鋳造
} 二次冷却技術

\author{
手嶋 俊雄 ${ }^{*}$. 北川融*2.宮原 忍* \\ 舟之川 洋 ${ }^{* 3}$. 小沢 宏一 $* 3 \cdot$ 沖本 一生 ${ }^{* 3}$
}

\section{The Secondary Cooling Technology of Continuous Casting for Production of High Temperature and High Quality Slab}

\author{
Toshio Teshima, Tòru Kitagawa, Shinobu Miyahara, \\ Hiroshi Funanokawa, Koichi Ozawa and Kazutaka Окімото
}

\begin{abstract}
Synopsis :
Delivery of sound slabs at high temperature is one of the most important conditions for the caster to realize the direct rolling (HDR) practice. Secondary cooling system was to be modified to make plan of Fukuyama No. 5 machine for HDR practice. To improve the uniformity and the controllability of cooling intensity, an air-mist cooling nozzle was newly developed. The developed nozzle has several features such as small amount of air consumption, stable spray pattern, easy maintenance, and others. Empirical equation to describe the cooling intensity of the air-mist cooling nozzle was obtained as a function of its operational factors. Evaluation of the nozzle performance in the secondary cooling zone was carried out through plant test with existing casters prior to the installation of No. 5 machine. Improvement of surface qualities of slabs was confirmed as the results of the test. Average heat transfer coefficient of the secondary cooling zone was also determined. Based on the knowledge, the secondary cooling zone and the reheating zone of No. 5 machine was designed and operated. Sound and high temperature slabs are delivered by the caster to realize the smooth HDR operation.
\end{abstract}

Key words : continuous casting ; cooling ; low carbon steel ; process control.

\section{1. 緒}

言

熱間直送圧延の実施には，鋳片の表面および内部の欠 陷防止，圧延開始時の鋳片温度確保，操業の安定が必須 の条件である．以上の観点から連続鋳造（以下，連鋳と 略記）の二次冷却では，鋳片の割れ欠陥の防止，クレー ター長の制御のために, 均一な冷却と自在な冷却強度制 御が可能であることが望まれる。これらのニーズから二 次冷却方法が見直され，従来のスプレーノズルに代わつ て, 低空気消費型の気水ミスト (以下, ミストと略記) ノズル ${ }^{1)}$ が採用され，表面割れ低減効果 ${ }^{233)}$ や優れた冷 却能4)-7) に関する数多くの報告がなされている．NKK においても熱間直送圧延を指向する福山 No. 5 連鋳機 （昭和 59 年 9 月稼動）にミスト冷却を適用すべく, ミ ストノズルの開発を昭和 55 年より開始した.
ミストノズルに関する報告には液滴の微細化が均一冷 却性に寄与していると記述されている1). しかしながら 液滴径の冷却能に対する寄与を定量的に評価した報告は 少ない.またノズル高さの影響は従来のスプレー冷却で は無視できたが9), ミスト冷却では冷却能が液滴の衝突 速度にも依存しており ${ }^{8)}$, 衝突速度の減衰を考えれば, ノズル高さの冷却能への影響は大きいと推定される。し かし衝突速度と噴射距離の関係を報告した例も少ない. 従つて冷却能に対する液滴径の寄与や噴霧条件の影響を 明確にすることは，ミストノズルの開発及び使用条件の 適正化をはかる上で重要である．鋳片幅方向の均一冷却 を考えるときロール間のノズル配列は適正に設定すべき であるが，その指標に関する報告はなく，設備化の際の 問題点である.

そこで本報告では，NKK が開発したミストノズルの 昭和 62 年 11 月 12 日受付 (Received Nov. 12, 1987)

* NKK 鉄鋼研究所 (Steel Research Center, NKK Corporation, 1 Kokan-cho Fukuyama 721)

*2 NKK 鉄鋼研究所 工博 (Steel Research Center, NKK Corporation)

*3 NKK 福山製鉄所 (Fukuyama Works, NKK Corporation) 
主な仕様と特徴，ノズル噴霧特性とミスト冷却能の関係 について述べる．ついで No. 5 連鋳機への応用を想定 した福山 No. 3, No. 4 スラブ連鋳機でのミストノズル 実機適用試験結果について述べ, 最後にNo. 5 連鋳機 での高速鋳造時の二次冷却技術と機内断熱帯での鋳片保 温技術について記述する。

\section{2. 開発したノズルの仕様と特幑}

ミストノズルは以下の基本仕様をもとに開発した.

1 ) 流量（水, 空気）が低圧力で制御できること.

2 ) 空気消費量は $0.8 \mathrm{Nm}^{3} / \mathrm{min}$ ·個以下とする.

3 ) 水量分布が流量変更に影響されないこと.

4 ）噴霧角度が流量変更に影響されないこと.

5 ）ノズル閉塞は皆無であること.

6 ) ノズル設定高さはロール径以下とし，ノズルチッ プ径は $30 \mathrm{~mm}$ 以下とする.

以上の仕様を，ほぼ満足するミストノズルを開発する ことができた．以下に開発したノズルの特徴を簡単に説 明する。

\section{$2 \cdot 1$ 椎造}

開発したミストノズルの構造を Fig. 1 に示す. ミス トノズルは水と空気の供給管, 混合配管, ノズルチップ から構成されている. 水と空気の供給管内には，流量を 制御するためのオリフィス（以下，配管オリフィスと記 す）が設置されている. ノズルの噴霧特性（水量分布, 衝突压分布, 液滴径分布）を決定するのはノズルチップ の構造であるが, 混合配管, 各供給管の構造についても, ノズルの噴霧特性との関係を調査した。ミストノズルの 配管構造は Fig. 1 の夕イプのほかに，一方の供給管が 混合配管と二重管を構成する夕イプのもの ${ }^{1)}$ が開発され

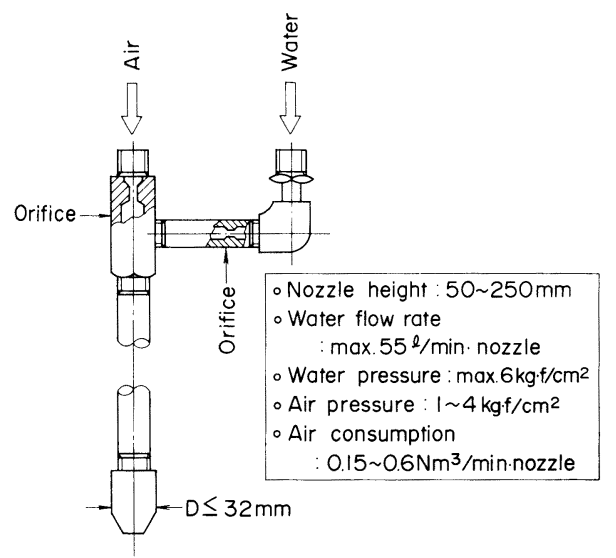

Fig. 1. Schematic diagram of newly developed mist nozzle.
ているが, 共通していえることは,これら配管構造が, 水量分布の対称性, 液滴径分布, 低水量域でのミスト間 欠噴射現象に影響する点である。これらの観点から開発 したミストノズルでは水と空気の供給管の混合配管への 接続位置, 配管オリフィス位置, ノズル開孔部と配管オ リフィスの断面積比を検討しその適性化をはかつた.

ノズル閉塞はノズル開孔部と水配管オリフィスに発生 する. 両者は上述のようにノズルの噴霧特性への影響を 考え, 一定の比率の寸法が設定されるが特に閉塞の可能 性が高い水配管オリフィスには下限值を設定して開発に 当たつた. No. 5 連鋳機には $3.8 \sim 7.6 \mathrm{~mm} \phi$ の範囲の水 配管オリフィスをもつ 8 種類のミストノズルを開発し た.

\section{$2 \cdot 2$ 開発したノズルの喷汿上の特幑}

鋳片鋳造方向（噴霧厚み方向）と鋳片幅方向（噴霧長 手方向）のミストの広がりは均一冷却性ひいては鋳片の 割れ欠陥の発生に影響する. Fig. 2 にノズル先端形状 のことなる試作ミストノズル $\mathrm{A}, \mathrm{B}$ の噴霧角度 $\theta_{w}$ (噴霧 長手方向）と水量の関係を示す. 図より明らかなように, 低水量域で $\theta_{w}$ が低下する傾向があり, 空気圧をあげて 空気消費量を増大させても，その傾向は変わらない. $\theta_{w}$ の変化はノズルチップ構造に大きく依存しており， $\theta_{w}$ の変化の少ないノズルチップの構造の開発を行つた.

Fig. 3 にノズル直下の流量密度を $100 \%$ とした場合 の開発したノズルの水量分布の一例を示す。この場合, $5 \sim 35 \mathrm{l} / \mathrm{min}$ の水量範囲で $\theta_{w}$ は $116 \sim 118^{\circ}$ の範囲でし か変化しない. No. 5 連鋳機に適用した Fig. 3 以外の 開発したノズルにおいても $\theta_{w}$ の変化量は，使用水量範

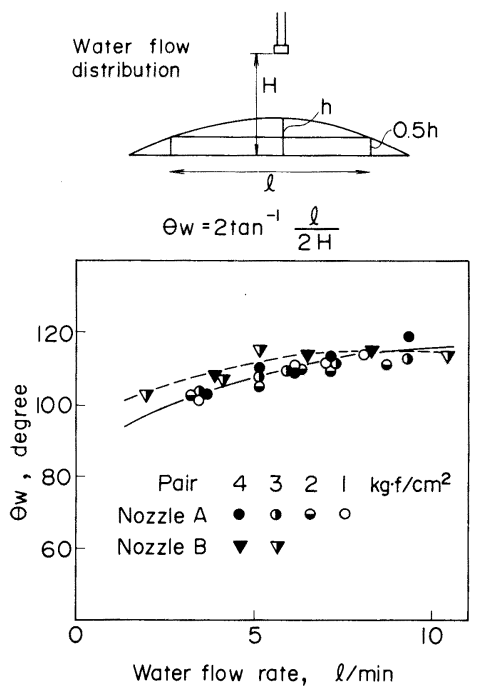

Fig. 2. Relation between water flow rate and $\theta_{w}$. 


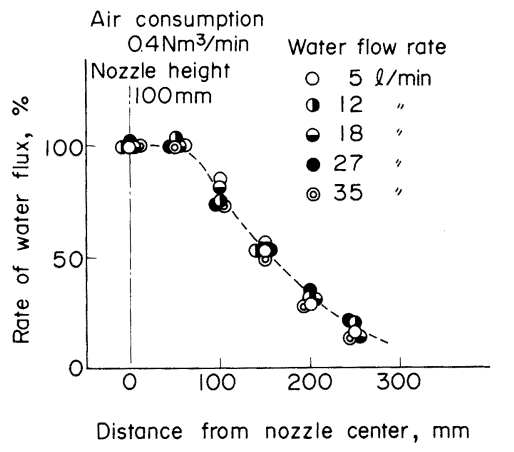

Fig. 3. Water flux distribution of newly developed mist nozzle.

聿ですべて $5^{\circ}$ 以内である.

更に開発したノズルの特徵は Fig. 3 に示すように気 水比が体積比で 11 80 の範囲で変化してもその水量分 布のパターンが変化しない点である. ミストノズルの冷 却能は, 水量分布だけで決まらないが, 均一冷却性を維 持するには流量を変更しても水量分布パターンが変化し ないことが必要でありこの観点で開発したノズルは優れ ている.

以上の開発したノズルの特徴によつて No. 5 連鋳機 では, 空気消費量を増大させることなく, 高速鋳造下で の二次冷却を強化することが可能となつた.

\section{3. ミストノズル噴霧特性と冷却能の関係}

ミストノズルは, 従来のスプレーノズルと比較すると 微細液滴, 広い噴霧領域, 衝突圧の増大という特徴が, 広い使用水量範囲で維持され, 均一冷却性, 冷却能に優 れているとされている4) 7). しかし噴霧状況を詳細に観 察すると，パ夕ーン内で液滴径に分布が見られ，水量分 布と衝突圧分布とは一致しない.そこで開発したノズル のうちから, 水量分布と液滴分布が異なる三種類のノズ ルを選び,ノズルの噴霧特性と冷却能の関係を調査した.

\section{$3 \cdot 1$ 実検方法}

背面より CA シース熱電対を埋め込んだ試片 (SS 41 相当の炭素鋼，サイズ $900 \mathrm{~mm} l \times 220 \mathrm{~mm} w \times 30 \mathrm{~mm} t)$ を $1100^{\circ} \mathrm{C}$ に均一加熱後, 所定の高さにセットした試験ノ ズルにて冷却を行い，その温度変化を計測した．主な実 験条件を Table 1 に, 計測点を Fig. 4 に示す. 実験条 件は一定空気消費量条件, 一定気水比条件, 一定水量条 件での評価ができるように設定した．また計測点は高さ の影響，ノズル直下からの位置の影響が整理できるよう に設定した。

測温実験と並行して, 各試験ノズルについて, 液滴径

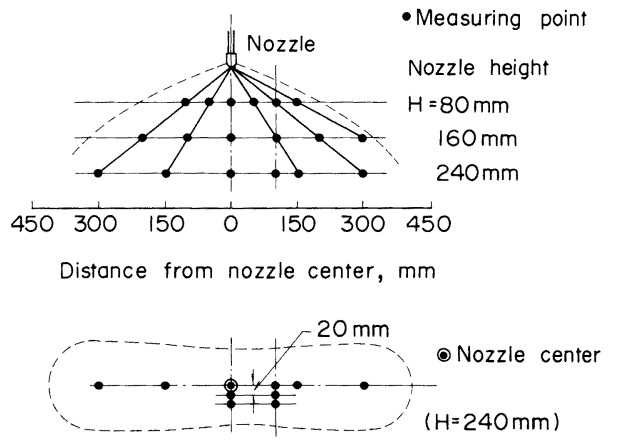

Fig. 4. Schematic diagram of measuring point.

Table 1. Experimental condition.

\begin{tabular}{cc|ccc}
\hline \multirow{2}{*}{$\begin{array}{c}Q_{a} \\
\left(\mathrm{Nm}^{3} / \mathrm{min}\right)\end{array}$} & $\begin{array}{c}Q_{w} \\
(1 / \mathrm{min})\end{array}$ & \multicolumn{3}{|c}{ Nozzle height, $H(\mathrm{~mm})$} \\
\cline { 3 - 5 } & & 80 & 160 & 240 \\
\hline 0.4 & 15 & $\bigcirc$ & $\bigcirc$ & $\bigcirc$ \\
0.4 & 10 & $\bigcirc$ & $\bigcirc$ & $\bigcirc$ \\
0.4 & 5 & $\bigcirc$ & $\bigcirc$ & $\bigcirc$ \\
0.2 & 5 & $\bigcirc$ & $\bigcirc$ & $\bigcirc$ \\
0.1 & 2.5 & 5 & $\bigcirc$ & $\bigcirc$ \\
0.3 & 5 & $\bigcirc$ & $\bigcirc$ & $\bigcirc$ \\
\hline
\end{tabular}

(O) Thermometric experiment and spray performance test

Spray performance test

(液浸法, ザウ夕径 $\left.{ }^{10}\right)$ で表示), 水量密度 $(10 \times 40 \mathrm{~mm}$ 升目のアクリル容器で計測), 衝突圧 (歪みゲージ, 受 圧面 $5 \mathrm{~mm} \oint$ ) の測定を各計測点ごとに実施した.

測温結果にもとづき各表面温度での熱伝達率の瞬時値 を一次元差分伝熱計算より算出した.こうして求めた局 所熱伝達率とノズルの噴霧特性の関係を重回帰分析より 求めた。 またノズルの噴霧特性のなかの衝突圧分布, 液 滴径分布については使用条件との関係を重回帰分析にて 求めた。

\section{$3 \cdot 2$ 実耠結果}

まず局所熱伝達率 $h\left(\mathrm{kcal} / \mathrm{m}^{2} \mathrm{~h}^{\circ} \mathrm{C}\right)$ は( 1$)$ 式で示すよ うに衝突圧 $P\left(\mathrm{kgf} / \mathrm{m}^{2}\right)$, 水量密度 $W\left(\mathrm{~m}^{3} / \mathrm{m}^{2} \cdot \mathrm{s}\right)$, 鋳片 表面温度 $T_{s}\left({ }^{\circ} \mathrm{C}\right)$ で決定された.

$$
h=a_{1} \cdot P^{0.2673} \cdot W^{0.3738} \cdot 10^{-0.0016 \cdot T_{s}}
$$

ここで $a_{1}$ は定数である.この式は輻射冷却分を含み， その適用可能範囲は $T_{s}=500 \sim 800^{\circ} \mathrm{C}$ である.

次に, 衝突圧 $P$ の分布はノズル高さ $H(\mathrm{~m})$, 水量密 度 $W$ および液滴径 $D(\mathrm{~m})$ で $(2)$ 式のように決定され た.一方液滴径 $D$ の分布は $(3)$ 式に示すように, 空気 消費量 $Q_{A}\left(\mathrm{Nm}^{3} / \mathrm{s}\right)$ とノズル開孔面積 $A\left(\mathrm{~m}^{2}\right)$ で主に決 定された.

$$
\begin{aligned}
& P=a_{2} \cdot\left(H / \cos \alpha_{i}\right)^{-0.4235} \cdot W^{0.6356} \cdot D^{-1.317} \\
& D=a_{3} \cdot Q_{A}^{-0.8604} \cdot A^{1.0142} \cdot W^{0.0553}
\end{aligned}
$$

$\left(1 / \cos \alpha_{i}\right)^{-n}$ 
ここで $\alpha_{i}$ は計測点とノズルセンターがなす角度 $\left({ }^{\circ}\right)$, $a_{2}, a_{3}$ は定数で $n$ はノズルチップ構造で決定される定数 （通常 0.45）である.

( 2 )式において $\left(H / \cos \alpha_{i}\right)$ は噴射距離で，そのべき 数は 0.5 に近い.すなわち衝突压は距離の $1 / 2$ 乗に近 い減衰をしていることを示している.

また $(3)$ 式において， $Q_{A}{ }^{0.8604} / A^{1.0142}$ のそれぞれの べき数は 1 に近く，ノズル開孔部での空気噴射速度と見 なすこともできる，すなわちノズル開孔部の空気平均噴 射速度が大きくなると液滴径は微細となり, 一方 $(2)$ 式 から衝突圧は増大することになる.

\section{4. ミストノズル実機適用結果}

開発したミストノズルはNo. 5 連鋳機の適用に先立 ち, No. 3 連鋳機での試験と No. 4 連鋳機への設備化を 実施し二次冷却帯での冷却特性および鋳片表面性状に及 ほす影響を調査した。以下にNo. 3, No. 4 連鋳機にお いてミスト冷却に関して得られた知見のいくつかを説明 する.

\section{$4 \cdot 1$ 複数ミストノズル噴霛時のミストの相互干涉}

Fig. 5 に 2 本のミストノズルを同時に噴霧した時の 水量分布と衝突圧分布を示す. 図中水量分布はノズル直 下の値との比で示している. ノズルの設定条件はノズル 設定高さ $100 \mathrm{~mm}$ ，ノズル間距離 $385 \mathrm{~mm}$ である. 両ノ ズルの中間には互いの噴霧が干渉しあい, 水量密度の上 昇の割には衝突圧が増加しない領域（以下, 干涉帯と記 す）があらわれる．この現象は噴霧パターン内の気流の 干渉によるものと推定され, 従来のフラットノズルでは 観察されないものである.

Fig. 5 の各分布をもとに(1)式を用い各位置での熱 伝達率を算出しノズル直下との比率をとると Fig. 6 に

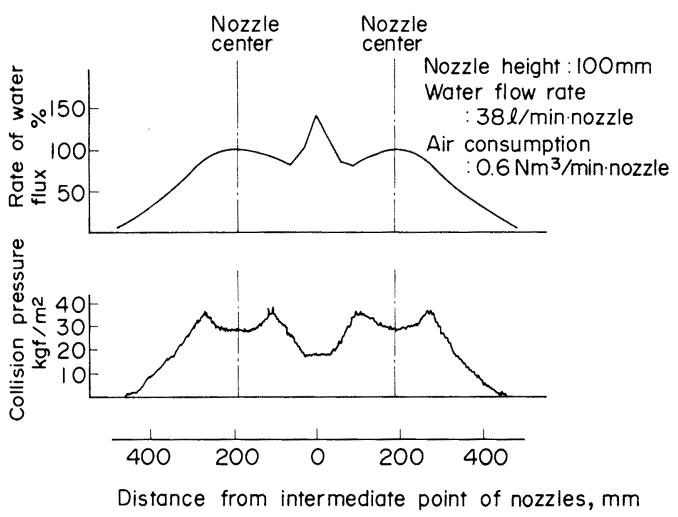

Fig. 5. Distribution of water flux and collision pressure in case of double mist spray.
示す冷却強度分布が得られる. Fig. 5に示した干涉帯で は結果的に冷却強度の変化は少なく鋳片幅方向の均一冷 却は十分に確保されていると推定される．以上の干涉带 の冷却能については実機測温試験で検証しその妥当性を 確認している.

以上の理由から,ノズル間距離は干涉带での水量分布, 衝突圧分布をもとにその冷却能を把握した上で行うべき である，しかしながら，水量変更にともなう噴霧角度 $\theta_{w}$ が大きく変化すると干涉帯での冷却強度がノズル直 下と大きく異なり鋳片幅方向の不均一冷却をひき起こす ことになる.この点で開発したノズルは Fig. 3 に示し たように $\theta_{w}$ の変化が少なく有利である.

\section{$4 \cdot 2$ 二次冷却帯での平均熱伝達率}

実機ではミスト冷却による抜熱のほかに，ロールによ る抜熱と輻射，対流による抜熱があり，これらを総括し た平均熱伝達率の推定式が二次冷却パターンを決定する ために必要である.そこで No. 3 連鋳機でのミストノ ズル実機試験において，モールド直下より各冷却ゾーン ごとに鋳片表面温度を 2 色式測温計と溶着式熱電対を用 いて測定し，その結果から伝熱計算により，二次冷却帯 での平均熱伝達率 $h_{m}$ の推定式を求めた。 その推定式を (4)式に示す.

$$
h_{m}=280.56 \cdot f_{a}^{0.1373} \cdot f_{w}^{0.382} \cdot k_{T} \cdots
$$

ここで $h_{m}$ は二次冷却带での平均熱伝達率 $\left(\mathrm{kcal} / \mathrm{m}^{2} \mathrm{~h}^{\circ} \mathrm{C}\right), f_{a}$ は空気流量密度 $\left(\mathrm{Nl} / \mathrm{m}^{2} \mathrm{~s}\right), f_{w}$ は水量 密度 $\left(\mathrm{l} / \mathrm{m}^{2} \mathrm{~s}\right), k_{T}$ は季節係数 $(0.9 \sim 1.0)$ である.

\section{3 鋳片表面割れ低減効果}

ミスト冷却の鋳片表面割れ低減効果については，既に 数多くの報告 ${ }^{23) 111)}$ がある.ここでは No. 3, No. 4 連鋳 機で得られた鋳片表面割れ低減の効果の一部を紹介す る.

Fig. 7 にミスト冷却の実施位置とスラブ表面の単位

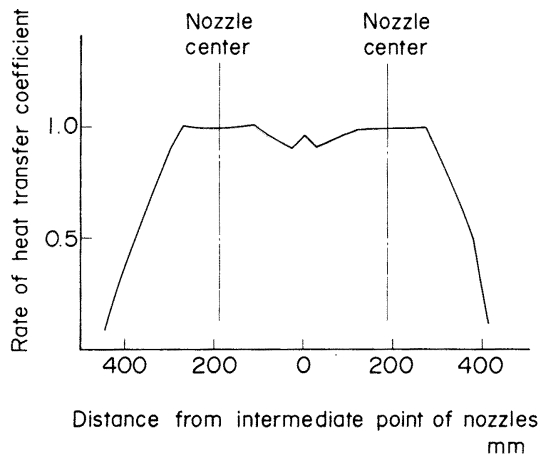

Fig. 6. Distribution of heat transfer coefficient in case of double mist spray. 


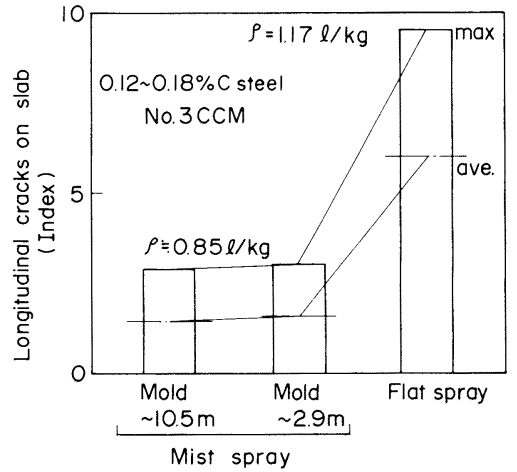

Fig. 7. Effect of mist spray on longitudinal cracks.

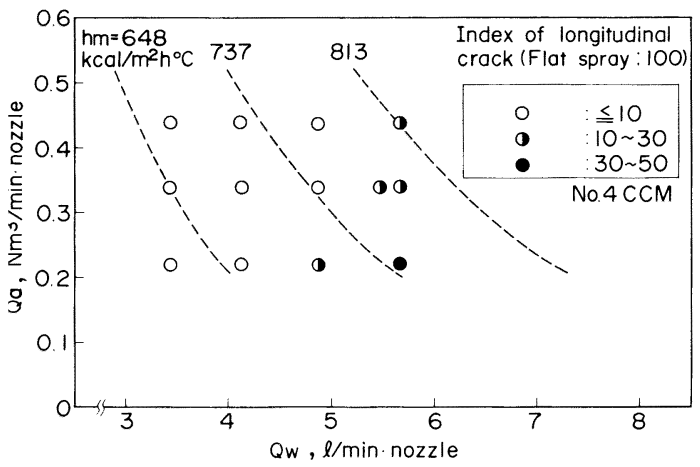

Fig. 8. Relation between flow rate of water $\left(Q_{w}\right)$, air $\left(Q_{a}\right)$ and longitudinal crack.

面積当たりの縦割れ発生個数を指数化したものとの関係 を示す ${ }^{11)}$. 縦割れに対するミスト冷却の効果は凝固殻 が薄く, 強冷却する二次冷却帯上部で顕著である.

Fig. 8 にはモールド直下の冷却ゾーンでの 40 $\mathrm{kgf} / \mathrm{mm}^{2}$ 級 $\mathrm{Si}-\mathrm{Mn}$ 鋼の縦割れ発生状況を示す。図中 $Q_{a}, Q_{w}$ はノズル 1 本当たりの空気と水の流量である. また，(4)式から求めた平均熱伝達率を破線にて示す.

Fig. 8 には, 冷却強度が大きい場合でも空気消費量を 確保することで，縦割れの発生を抑制できることが示さ れている.これは気流による衝突後の水滴の飛散効果の ためと考えられる.

横割れについてはミスト冷却の適用だけでは，対策が 不十分で鋳片コーナー過冷防止技術が必要である.

\section{No. 5 連鋳機高速鋳造時の二次冷却技術}

No. 5 連鋳機 ${ }^{12)}$ は全長 $42 \mathrm{~m}$ のうち, モールド直下か ら $25 \mathrm{~m}$ が二次冷却带で残り $16 \mathrm{~m}$ が機内断熱帯で構成 されている. 二次冷却带ではロール間に設置した開発し たミストノズルを，鋳片幅に応じて高さと間隔を可変さ

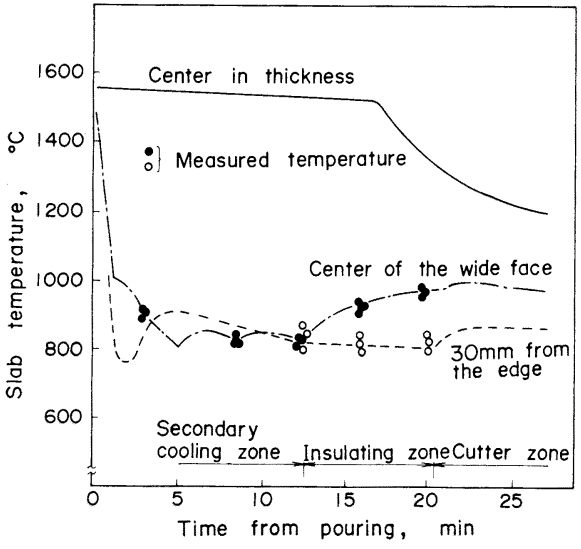

Fig. 9. Transition of the slab temperature (Calculation).

せ，鋳片エッジの過冷を防止するシステムを採用してい る. 凝固は機内断熱帯で完了させるようにし二次冷却で 低下した鋳片温度を凝固潜熱を利用し復熱させている。 以下に No. 5 連鋳機の二次冷却技術と機内断熱帯での 復熱効果について記述する.

\section{$5 \cdot 1$ 二次冷却パターンの検討と検証}

No. 5 連鋳機の二次冷却パターンは (4)式を用いて検 討を行つた。検証した冷却パターンを検証するため, No. 5 連鋳機の稼動以降, 鋳造速度 (以下, $V_{C}$ と略記) 1.4 2.0 m/min での鋳片表面温度を 2 色式測温計にて 測定した。また $V_{C}=2.0 \mathrm{~m} / \mathrm{min} て ゙$ 鋳片への鋲打ち込み 試験を行い, クレーター長を調査した.

Fig. 9 に $V_{C}=2.0 \mathrm{~m} / \mathrm{min}$ での測温結果と伝熱計算結 果の比較を示す．機内断熱帯での鋳片放熱については後 述するが機内断熱带を含め機内での鋳片温度推移に関し ては，伝熱計算結果と測温結果とは良く一致した。

No. 5 連鋳機では熱延の生産との同期化を主目的に鋳 造の高速化 ${ }^{12)}$ をはかつた。このときの冷却パターンの 検討に(4)式を用いた伝熱計算が有効に用いられ次節に 述べる内部割れ発生防止に効果を示した。

\section{$5 \cdot 2$ 高速鋳造時の二次冷却制御}

鋳造の高速化にともなつて鋳片の品質で問題となるも のの一つとして, 凝固界面に発生する内部割れがある. そこで, 高速化にあたつては種々の $V_{C}$, 二次冷却パター ンでの鋳片内部割れ発生状況を鋳片鋳造方向のサル ファープリントにて調査した. Fig. 10 に内部割れ発生 状況の一例を示す．鋳造条件としては，低炭素アルミキ ルド鋼, $V_{C}=2.5 \mathrm{~m} / \mathrm{min}$, 比水量 $1.3 \mathrm{l} / \mathrm{kg}$ である. 内 部割れの機内での発生位置は伝熱計算より求めた凝固厚 のプロフィルとサルファープリント上の内部割れの表層 


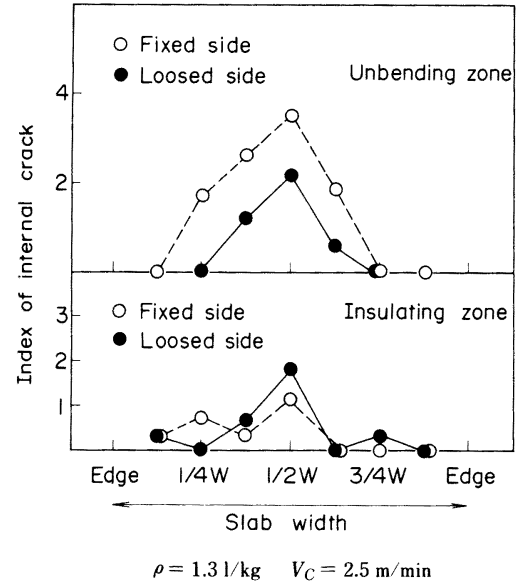

Fig. 10. Example of internal crack distribution.

からの距離の測定結果の対比から求めた。 その結果，内 部割れの多くは下部矯正帯で集中的に発生するが，一部 機内断熱帯においても発生している。またその発生は, ほとんどの場合，鋳片の上下の面に見られた．各鋳造条 件での鋳片の凝固界面にかかる総歪み量 $\varepsilon_{T}$ を(5) (8)式より計算した。そして各鋳造条件での内部割れの 発生状況との対比から, 低炭素アルミキルド鋼では総歪 み量が $0.5 \%$ を超えると内部割れが発生していること が判明した。

$$
\begin{aligned}
& \varepsilon_{T}=\varepsilon_{B} \varepsilon+\varepsilon_{U}+\varepsilon_{M} \\
& \varepsilon_{B}=17.5 W_{j} l / F x^{2} \\
& \varepsilon_{U}=100(D / 2-x) \|\left\{\left(1 / R_{i}\right)-\left(1 / R_{i-1}\right)\right\} \quad \cdots(7) \\
& \varepsilon_{M}=300 \delta_{M x} / l^{2}
\end{aligned}
$$

ここで $\varepsilon_{T}, \varepsilon_{B}, \varepsilon_{U}, \varepsilon_{M}$ はそれぞれ総歪み量, バルジ ング歪み量, 矯正歪み量, ミスアライメント歪み量 $(\%)$ で $W_{j}$ は溶鋼静圧 $(\mathrm{kgf}), l$ はロールピッチ $(\mathrm{mm}), x$ は 凝固殻厚 $(\mathrm{mm}), F$ は表面から $0.3 x$ 位置での鋼の塑性 変形抵抗 $\left(\mathrm{kgf} / \mathrm{mm}^{2}\right), D$ は鋳片厚 $(\mathrm{mm}), R_{i}, R_{i-1}$ は 連鋳機矯正带での曲率半径 $(\mathrm{mm}), \delta_{M}$ はミスアライメ ント量 $(\mathrm{mm})$ である.

No. 5 連鋳機は多点矯正, ロールピッチの短縮化, 分割ロールの採用を行つているが，高速鋳造化は $\varepsilon_{B}$ を 著しく増加させた. Fig. 10 に示す場合でも $\varepsilon_{T}$ の半分 以上を $\varepsilon_{B}$ が占めている.このため $(5)$ 〜 $(8)$ 式と伝熱 計算から $\varepsilon_{T}$ が $0.5 \%$ 以下になる強冷却パターンを各 $V_{C}$ ごとに算出し，操業に適用した．その結果, 内部割 れを完全に防止することができた。

なお高速鋳造の適正強冷却での鋳片表面割れは軽微で 問題にはなつていない．鋳片表面割れについては，鋼種 構成, 使用パウダー, 振動条件 ${ }^{13)}$ の影響が大きく, ミ

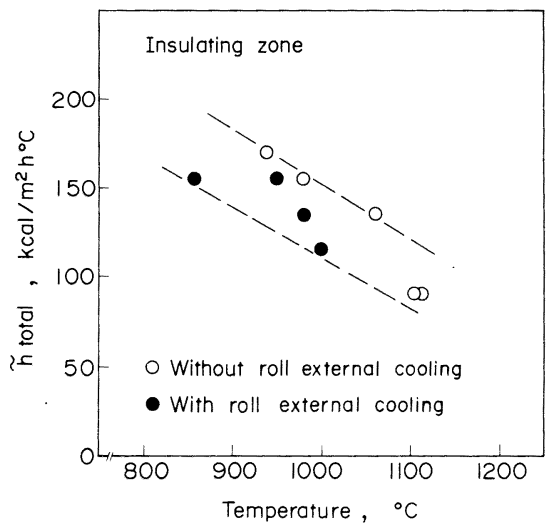

Fig. 11. Relationship between average heat transfer coefficient and slab surface temperature.

スト冷却の効果だけをみることはNo. 5 連鋳機では行 つていないが, Fig. 8 で説明した理由からミスト冷却 も，その低減に寄与していると考えられる.

\section{$5 \cdot 3$ 機内断熱帯での鋳片放熱挙動}

熱間直送圧延の場合，機内断熱带での凝固完了時の鋳 片温度分布とその後の搬送時の保温, 搬送速度が重要で ある。そこで機内断熱帯における鋳片の放熱挙動を把握 するため, 鋳片方向数箇所で 2 色式測温計によりスケー ルを除去した状態の鋳片表面温度を測定した。またロー ドセルによるロール荷重の測定, 溶着式熱電対による ロール表面の測温を並行して実施しロールの抜熱量を推 定した. Fig. 11 に鋳片表面測温結果にもとづき伝熱計 算から求めた機内断熱帯での平均熱伝達率 $\tilde{h}_{\text {total }}$ と鋳片 表面温度の関係を示す。なお $\tilde{h}_{\text {total }}$ はロールへの伝導に よる熱伝達率 $h_{\text {cond }}$, 輻射による熱伝達率 $h_{\text {rad }}$ および対 流による熱伝達率 $h_{\text {conv }}$ の総和である．Fig. 11 では $\tilde{h}_{\text {total }}$ が鋳片表面温度と負の相関を示している。この結 果は $h_{\text {cond }}, h_{\text {rad }}, h_{\text {conv }}$ のいずれかが鋳片表面温度上昇で 大きく低下することを示唆している.

3 者のうち $h_{\text {conv }}$ は $5 \sim 10 \mathrm{kcal} / \mathrm{m}^{2} \mathrm{~h}^{\circ} \mathrm{C}$ と見積もられ ており ${ }^{14)}, \tilde{h}_{\text {total }}$ への影響は小さい. 次に $h_{\text {cond }}$ はロール の設定条件が同じ場合には，高温鋳片ほどロール接触長 は大きくなるので, むしろ増大傾向にあると考えられる. 実機ではロール荷重測定，ロール測温結果でもロールと の接触長が鋳片が高温になるほど増大することを示して いた．従つて Fig. 11 の $h_{\text {total }}$ と鋳片表面温度の関係は 残る $h_{\text {rad }}$ により生じたことになる， $h_{\text {rad }}$ が鋳片表面温 度の上昇にともなつて減少するのは，鋳片表面に生成す るスケールの影響のためと考えられる．鋳片表面のス ケールは時間とともに放物線則に従つて成長し, 高温ほ 
ど成長速度が大きい15)。しかしながら機内で観察され るスケールの成長厚みは，かなり薄い，従つて鋳片表面 温度の上昇によつて $h_{\text {rad }}$ が低下した理由はスケールの 構造にあると考えられる。この点について森岡ら ${ }^{15)} は$ スケール層の鋳片近傍には多孔質の $\mathrm{FeO}$ 層が形成され ていると報告しており，その多孔質層が断熱効果をしめ すと考えられる．またスケールの除去が高温鋳片ほど容 易であることから，高温鋳片では，さらにスケール層と 鋳片間に局所的な巨大空隙が形成され大きな断熱効果を 示したと推定される.

No. 5 連鋳機の機内断熱帯は単に輻射伝熱低減だけで なく, 二次冷却の強化で低温になつた鋳片表面に断熱層 をもつスケールをすみやかに形成させ鋳片の保温を強化 する作用もあると考えられる.

\section{$5 \cdot 4$ ロール抜熱低減対策}

一般にロール荷重 $P_{R}(\mathrm{kgf})$ は以下の式で表される.

$P_{R}=k_{m} \cdot b_{m} \cdot l_{d} \cdot Q_{P}$

ここで $k_{m}$ は鋳片の平均变形抵抗 $\left(\mathrm{kgf} / \mathrm{mm}^{2}\right), b_{m}$ は ロールと鋳片の接触幅 $(\mathrm{mm}), l_{d}$ はロールと鋳片の接触 長 $(\mathrm{mm}), Q_{P}$ は压下力関数である. いま $Q_{P}=1$ として (9)式より，ロールと鋳片の接触長 $l_{d}$ を求める $(10)$ 式 を導き, No. 5 連鋳機断熱帯でのロール荷重測定結果を 用いて，そのロール位置での接触長 $l_{d}$ を求めた.

$$
l_{d}=P_{R} /\left(k_{m} \cdot b_{m}\right)
$$

結果をFig. 12 に示す. 図中破線で囲つた点は中心偏 析対策でロールテーパを強化した領域におけるデータで ある. 機内断熱带には内部冷却型の 1 本ロールが使用さ れている.また図中スリットロールとは表面に溝をつけ たロールで，フラットロールとは従来の平滑面をもつ ロールのことである. フラット 1 本ロールと高温鋳片が 接触した場合には熱応力によるロールの大きな曲がりが 発生する、ロールの曲がりは内部割れの発生, 中心偏析 の悪化といつた品質上の問題をひき起こす ${ }^{16)}$. 前述の 二次冷却の強化は機内断熱带での鋳片温度も考慮して実 施されているが, ロールの熱変形対策としてロール外部 冷却とスリットロールの採用試験を行つた。その効果は Fig. 12 に示寸ように接触長の低減としてあらわれてい る. 現在この領域はすべてスリットロール化されており ロールによる抜熱の低隇に大きく寄与している.

以上のデー夕をもとに機内断熱帯での復熱効果を二次 元差分法による伝熱計算により求めた結果を示す（Fig. 13).この計算は実機鋳造実績デー夕をもとに行つた. 図中で機内断熱帯入側の鋳片コーナー近傍での表面温度 上昇は二次冷却帯でのコーナー過冷防止技術の効果であ る. 機内断熱帯入側でみられる鋳片中央の低温域は機内

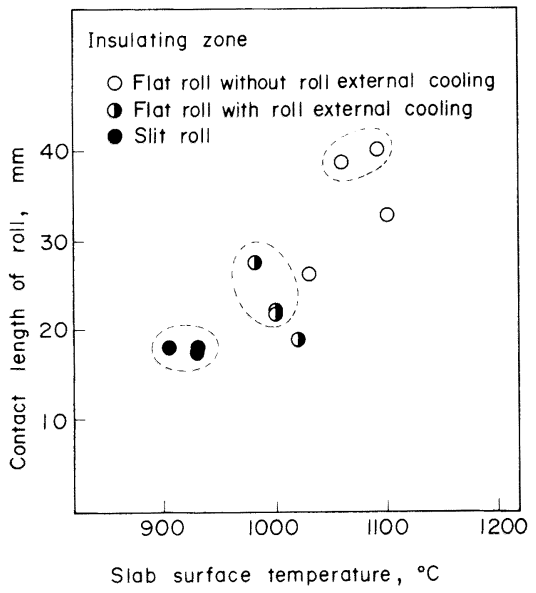

Fig. 12. Relation between contact length of roll and slab surface temperature.

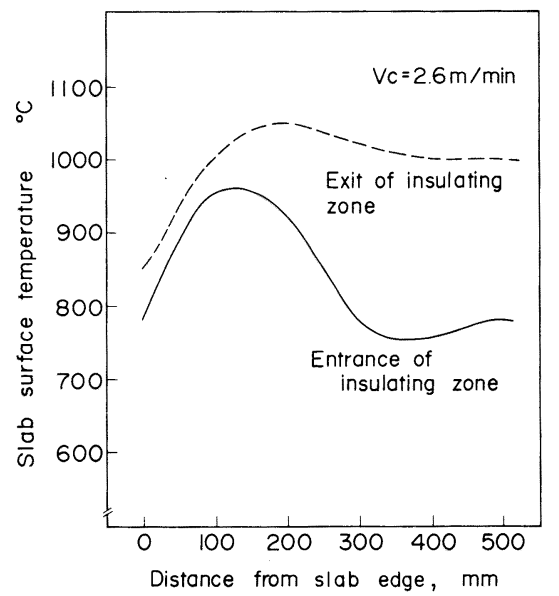

Fig. 13. Effect of insulating zone on slab surface temperature (Calculation).

断熱带での断熱低減対策によつて, 出側ではほぼ解消さ れていることが Fig. 13 に示されている.

\section{6. 結言}

熱間直送圧延の必須条件の一つである高温無欠樎鋳片 製造のため,ミストノズルを開発し，No. 5 連鋳機に適 用し高速鋳造での二次冷却技術を確立した。 その結果を 以下にまとめる。

1 ）噴霧角度と水量分布が使用水量の变更に対し, 安 定なミストノズルを開発した。

2 ）ミストノズルの冷却能とノズルの噴霧特性の関保 と使用時の考虑すべき点を調查, 整理した.

3 ）ミスト冷却の表面割れに対する効果を確認した. 
4 ）二次冷却の適正強化をはかり内部割れなどのない 健全な鋳片の高速鋳造を可能にした。

5 ) 機内断熱帯での鋳片の放熱挙動を調査し，ロール による抜熱の低減技術の効果などを確認し鋳片温度確保 技術を確立した。

おわりにあたり本報告に使用したノズル噴霧特性の測 定を実施していただいた株式会社「いけうち」(ミスト ノズル共同開発）の皆様に感謝を申し上げます。

\section{文献}

1 ) 三塚正志, 福久陽三, 和気 誠, 岡島正樹, 宮下 永, 武田安夫: 鉄と鋼, 70 (1984), p. 76

2 ) 河野拓夫, 島 孝次, 桑原達朗, 山本利樹, 和気 誠, 常岡 聡: 鉄と鋼, 68 (1982), p. 118

3 ) 德田 誠, 渡部忠男, 赤井芳弘, 川崎守夫, 中島敬治, 相馬正幸: 鉄と鋼，69 (1983)，Ｓ919

4 ) 岩佐 勝, 柴田充蔵, 工藤一郎, 大滝 明, 八塚 隆, 野口三和人: 鉄と鋼，68（1982），S848

5 ) 川崎守夫, 渡部忠男, 浜名孝年, 中島敬治, 高島啓行, 播木道春: 鉄と鋼，69 (1983)， S 168
6 ）㭡崎誠治，宮下 永，土岐正弘，安部勇一: 鉄と鋼，69 (1983), S 210

7 ) 松川敏㻆, 油原 晋, 小島信司, 藤山寿郎, 宮川昌治, 馬淵昌樹: 鉄と鋼, 73 (1987), S 154

8 ）特別報告書 No. 29, 鋼材の強制冷却（日本鉄鋼協会編） (1978), p. 58

9 ) $H$. Müller, $R$. Jeschar and $C$. Zellerfeld: Arch. Eisenhüttenwes., 44 (1973), p. 589

10）棚沢 泰: 機械の研究, 15 (1963), p. 9

11）半明正之, 辻野雅章, 瀬良泰三, 近藤恒雄, 小沢宏一: 鉄と鋼, 69 (1983), S 924

12）小谷野敬, 白谷勇介, 内田繁孝, 和田 勉, 政岡俊雄: 鉄と龬, 72 (1986), p. 2233

13）水上秀昭, 川上公成, 北川 融, 鈴木幹雄, 内田繁孝, 小松喜美: 鉄と鋼, 72 (1986), p. 1862

14）特別報告書 No. 11, 連続龬片加熱炉における伝熱実験と 計算方法（日本鉄鋼協会編）（1970）, p. 63

15）鉄鋼工学講座 11, 鉄龬腐食科学 (1972), p. 39 [朝倉書店]

16）荻林成章, 西本清治, 向井達夫, 山田 衛, 内藤俊太: 鉄と鋼, 71 (1985), S 215 